\title{
EMERGENCE AND EPIDEMICS OF A NEW DISEASE IN ARAGUAIA VALLEY: ANTHRACNOSIS OF COTTON CAUSED BY Colletotrichum truncatum, VARIETAL REACTION AND DIFFICULTIES OF CHEMICAL CONTROL
}

\author{
EPIDEMIAS DA ANTRACNOSE DO ALGODOEIRO NO VALE DO ARAGUAIA \\ CAUSADA POR Colletotrichum truncatum REAÇÃO DE CULTIVARES E \\ DIFICULDADES DE CONTROLE QUÍMICO
}

\author{
Fernando Cezar JULiATTI ${ }^{1}$; Fernanda Cristina JULIATTI ${ }^{2}$; \\ Breno Cezar Marinho JULIATTI ${ }^{3}$; Cristiane Aparecida de PAULA ${ }^{4}$ \\ 1. Universidade Federal de Uberlândia - UFU, Instituto de Ciências Agrárias - ICIAG, Laboratório de Micologia e Proteção de Plantas, \\ Uberlândia, MG, Brasil. juliatti@ufu.br; 2. Juliagro B, G \& P Ltda; 3. Juliagro, B,G \& P, Ltda. e 4. Grupo Bom Futuro - Campo Verde \\ - MT, Brasil.
}

\begin{abstract}
Cotton culture (Gossypium hirsutum L.) is trending in an upward expansion amidst Brazilian "cerrado". Due this growth, new pathosystems are growing in incidence on tropical fields in the region of Araguaia Valley - MT. Surveys and material collection were conducted out in production areas on two counties (Bom Jesus - MT and Canarana - MT), both regions represents a total amount of 50.000 hectares of cultivated area. The region also is characterized by succession areas previously sowed with soybean plants (main cover crop season). Previously surveys revealed the incidence of target spot (Corynespora cassiicola), ramularia spot (Ramularia areola) and cercosporiosis (Cercospora gossypii). Disease incidence is commonly observed on several crop management methods and cultivars. Due to a reduction in efficacy of chemichal control by fungicides spray programs, this disease is increasing and spreading in a faster rate in production areas with previous harvested soybean at the biggest soybean producer group in the world (Bom Futuro). Plants on field were selected due to differences in symptoms, and isolation methods were carried out on PDA (potatodextrose-agar) before "in vitro" pathogenicity tests conducted on seedlings, detached leaves and bolls (growth chamber conditions of $23^{\circ} \mathrm{C} /$ photoperiod of 12 hours). After Colletotrichum dextructor sp. pathogenicity confirmation, bioassays were carried out with several different fungicide's groups (i.e. registered for usage on Brazilian jurisdiction). This test consisted of the employment of a solution with $500 \mathrm{ppm}$ of each different fungicide/a.i. that is applied on infected bolls and detached leaves who were inoculated with the target pathogen (concentration of $10^{4}$ conidia per $\mathrm{mL}$ ). This test was followed by an infection (\%) evaluation during 10 days of incubation. The incidence/prevalence index (\%) was also evaluated at different parts of the plant (lower, middle, and upper canopy) on different cultivars/genotypes (130-150 days after sowing). A standard level of control by different fungicides, ranged between 0 to $100 \%$ of control. Two groups of cultivars/genotypes were separated after differences on resistance response, one with susceptible traits (FM 985 GLTP) and other with partial resistance traits. No immunity response was observed. We suggest that new efficacy tests should be carried out with combination of varietal response (resistance or tolerance) combined with other chemical fungicides for better understanding of synergism or positive interaction. Valuable information will highlight the best association for greater varietal response and yield against this necrotrophic pathogen (higher B0 - initial inoculum) survival during successive years of rotation main crop (cotton $\mathrm{x}$ soybean). Isolated spray of benzimidazoles, cupric (except cuprous oxide) and triple associations with triazoles or triazolinthione (prothioconazol) combined with strobilurins and carboxamides should be wisely administrated to manage this disease due to low efficiency (below 50\%). New field and laboratory essay must be carried out to input data about resistance risk and clarify damage levels on leaves and bolls impacting yield.
\end{abstract}

KEYWORDS: Anthracnosis. Cotton. New disease. Chemical control. Genetic Control. Management.

\section{INTRODUCTION}

Cotton plants (Gossypium hirsutum L.) usually are infected with fungal, bacterial, viral, and nematode generating depreciation of plant growth that will affect boll yield and quality of fibers. Foliar epidemics of fungi such as Ramularia areola, Cercospora gossypii, Alternaria macrospora, Stemphylium solani, Rhizoctonia solani and Colletotrichum gossypii var. cephalosporioides have 
been reported in Brazil and are growing in importance in recent years. The damage by an aggressor is fungus (biotrophic or necrotrophic), or bacteria in vegetative or reproductive parts, can reflect in addition losses to industrial product (cloth) performance. Adding up the Covid-19 Pandemic, after the oil prices fell worldwide contributed to the stimulation of synthetic fiber production that ended up affect the textile industry cost production per pound of cotton fiber weight. Ramularia spot is the main leaf disease, the optimum conditions for its development and development of field epidemics are stated in literature to a combination of $20-28^{\circ} \mathrm{C}$ and leaf wetness of at least 6 hours daily (mild rains or foliar dew). Also, incidence of sun (photo stimulation) on leaves, can lead to an abundant sporulation of the pathogen leading to defoliation of plants who also impairs the development of cotton bolls. Additional incidence of other leaf diseases caused by Cercospora spp., Alternaria spp., Colletotrichum gossypii var. cephalosporioides (ramulosis) could extend several impacts on plant overgrowth affecting the final products. Colletotrichum gossypii var. cephalosporioides characteristic conidia are ovoid with size of 6 to 17 $\mu \mathrm{m}$ with hyaline conidiophores generating numerous acervuli spikes, authors suggested that higher incidence usually is related to long periods of prolonged rain and its teleomorph form Glomerella gossypii Edg. was also described in Venezuela (COSTA, FRAGA, 1937; MALAGUTI, 1955). The pathogenicity and inoculation of several isolates can be confirmed by relatively simple methods, like an application of a solution of water and of conidia spray on younger cotton plants.

In the last 4 years, cotton became a great cover crop ("safrinha") option to Brazilian farmers after succession/rotation with soybean in previously first option of harvest season ("safra"), this led to a certain difficulty in obtaining superior genotypes with broad resistance to disease complex that affects both crops (surplus in initial inoculum B0). Genotypes such as Redenção and IAC 20 presents higher levels of resistance to leaf disease complex those as well are being unused over the years and became obsolete sources after showing lower yield on field (POLIZEL, JULIATTI, HAMAWAKI, PENNA, 2008). Currently, the most planted cultivars/genotypes in Brazil are the cultivar FM 985 GLTP and FM 911 GLTP, both shows superior boll quality and yield on the Araguaia Valley (northern region Mato Grosso state), but showed as well higher susceptibility that grew in importance in the last season (unknow etiology). This new disease was observed by farmers and growers in the region of Bom Jesus - MT and Canarana MT, they also reported that several fungicides spray (9-10 applications) could not reduce the higher levels of incidence thus affecting fiber quality and yield $\left(\mathrm{kg} \cdot \mathrm{ha}^{-1}\right)$. Several fungicide programs have been used by farmers, including the intense spray and rotation of several (multi-sites, strobilurins, triazoles and carboxamides) active ingredients. This also could be main reason of a growing concern that could be related to fungi isolates selection process on field after a wrong choice in timing spray and application interval in combination of fungicides groups without research data to support the Integrated plant disease management (IDM).

Vale do Araguaia - MT is a production region inside Brazilian transition between savannah (cerrado) and Amazon rainforest (equatorial climate), this region is characterized by well distributed precipitation closely to $2.000 \mathrm{~mm}$ by year during wet season (7 months) and a prolonged dry period (another 5 months). Cotton became a popular choice for growers after higher performance of yield and quality of cotton plants, who generates fibers with desirable characteristics. The averages in temperatures usually ranges between 25 to $28{ }^{\circ} \mathrm{C}$. Leaf wetness after prolonged dew periods and optimum temperature contributes to the development of several foliar fungal etiologies. In this scenario, of a chemical control losing efficacy compromising yield after the vegetative development and fiber loss quality being affected by growth regulators promotion, there is an urgent need to carry out systematic and periodic surveys on the main diseases that occur in this culture that is strategic for agribusiness in Brazil and Araguaia region. The development of data to support sustainable management programs with fungicides (chemical and biological combination) in different cultivars/genotypes must be priority to cotton phytopathological research.

\section{MATERIAL AND METHODS}

\section{Location of collection and sampling experiments}

The collections of symptomatic material were carried out in Bom Jesus - MT (Fazenda Malú of the Bom Futuro group - MT) and Canarana - MT (Fazenda Cocal - Bom Futuro group - MT). The collections were carried out in areas with higher incidence and severity of phytopathogens in the lower, medium, and upper cannopy of cotton plants in all cultivars/genotypes used experimentally and commercially by the farmer group. Samples of leaves, bolls and stems were stored in plastic bags and placed on foam boxes with ice $\left(10\right.$ to $\left.15^{\circ} \mathrm{C}\right)$ and 
transported to the Laboratory of Mycology and Plant Protection at the Institute of Agricultural Sciences in UFU (Uberlândia-MG) them stored again at $5{ }^{\circ} \mathrm{C}$ (refrigeration). Fungi isolation was conducted in PDA media (potato-dextrose-agar, with antibiotic agrimicina at $200 \mathrm{ppm}$ ) and placement at growth chamber $\left(23^{\circ} \mathrm{C}\right)$. Gerboxes tests were also conducted (wet growth chamber) at 20 different cultivars detached infected leaves, stems, and cotton bolls. The composition of genotypes/cultivars of Fibermax-Basf: FM 906 GLT, FM 911 GLTP, FM 944 GL, FM 954 GLT, FM 974 GLT, FM 975 WS and FM 985 GLTP possess technologies like Glitol (G), Liberty Link (L), Twin Link Plus (T) and Wild Strike (WS) technology, these OGM cultivars possess proteins related to resistance against defoliating caterpillars and glyphosate herbicide spray. Other plants samples had RX technology that confers partial resistance or tolerance to Ramularia areola, considered the main fungal disease of the crop. The multivariate samples were also composed by genotypes of Tropical Genetic Improvement: TMG $42 \mathrm{WS}$, TMG 44 B2RF, TMG 44 B2RF, TMG 47 B2RF, TMG $50 \mathrm{WS}$, TMG $61 \mathrm{RF}$, TMG $62 \mathrm{RF}$, TMG $81 \mathrm{WS}$ and TMG $91 \mathrm{WS} 3$. Lastly the cultivars 2106 GL, IMA 5801 B2RF, IMA $7501 \mathrm{WS}$ and IMA 8405 GLT genotypes from the Instituto Mato Grossense do Algodão - Cotton Mato Grosso Institute (IMA) were as well sampled and tested. Most of the samples tested possessed several OGM technologies that varied from multiple genes that confers resistance to defoliating caterpillars, to multispectral herbicide (glyphosate) spray resistance. The company holders described that some cultivars/genotypes possess different levels of tolerance/resistance against ramulose (Colletotrichum gossypii var. cephalosporioides), gall nematode infection (Meloidogyne spp.), bacteriosis (Xanthomonas campestris pv. malvacearum) and blue disease caused by cotton leafroll dwarf virus (CLRDV).

\section{Isolation in culture medium from possible plant pathogens}

To perform direct fungi isolation, sections of infected tissue were marginally cut close to the lesions (peripheral) or sporulation structures and placed in a moist chamber on Gerbox (ZAMBOLIM, PEREIRA, 2012), to obtain pure culture in PDA culture medium, routinely used to obtain isolates. Candidate cultures without the presence of saprophytic fungi, were selected to represents isolates with potential for association with the new pathology (disease). The candidate cultures obtained were grown in test tubes with PDA and stored by suitable methods for pathogenicity preservation. At least one hundred different samples were identified with presence of viruses or bacteria that could be contamination sources and were discarded as well (JULIATTI and POLIZEL, 2003; WATHINS 1968 and KIRKPATRICK, T.L.; ROTHROCK 2001).

\section{Inoculations and pathogenicity tests}

Inoculations were carried out on detached leaves and green cotton bolls not yet fully ripen or in the process of burst. Leaves and cotton bolls were superficially disinfected with a combination of solutions with $50 \%$ alcohol after submitted to in 2 $\%$ sodium hypochlorite, and then washed with sterile water. Samples (separating bolls from leaves) were packed in Gerboxes with a thin layer of moisted sterile germitest paper and then inoculated with conidia at a concentration of $10^{4}$ per $\mathrm{mL}$. Incubations were performed in growth chambers (GC) chambers at 12-hour photoperiod in $23{ }^{\circ} \mathrm{C}$ for 10 days. The evaluations consisted in incidence data whether the sample had pathogenic infection. Pair of leaves (unifoliolate leaf) of seedlings (cultivar NuOpal) were also inoculated, to confirm the etiology of the fungi involved (Koch postulate).

\section{Reaction of Genotypes / cultivars}

Genotypes resistance ranking was carried out in field with visual assessment of the prevalence index in each cultivar/genotype present in Bom Futuro group farms $(50.000 \mathrm{ha})$, located in the municipalities of Canarana - MT and Bom Jesus MT. Commercial plots of the following were evaluated: Fibermax (BASF) genotypes evaluated FM 906 GLT, FM 911 GLTP, FM 944 GL, FM 954 GLT, FM 974 GLT, FM 975 WS and FM 985 GLTP; IMA cultivars - 2106 GL, IMA 5801 B2RF, IMA $7501 \mathrm{WS}$ and IMA 8405 GLT; TMG materials - TMG 42 WS, TMG 44 B2RF, TMG 44 B2RF, TMG 47 B2RF, TMG $50 \mathrm{WS}$, TMG $61 \mathrm{RF}$, TMG 62 RF, TMG 81 WS and TMG 91 WS3. Sampling was carried out in the three parts of the plant (lower, medium and upper canopy) to determine the prevalence index in each cultivar/genotype canopy region. The average severity was also assessed based on the percentage of disease area on leaves at each production plot on field (stand) ranging from 0 to $100 \%$ area of infection. All field plots previously reported were sprayed at least 8 times.

Evaluation of fungicides on detached leaves and bolls 
Healthy bolls and leaves were harvest in two cultivars (DP 1746 and FM 985 GLTP), both respectively corresponded to a collection on a field experimental area inside the research station JuliAgro B, G \& P and LAMIP - UFU (growth chamber) both places are located in Uberlândia MG. This biological material was treated for asepsis in solutions containing alcohol, sodium hypochlorite and sterile distilled water. Samples them were packed in Gerbox containing sterile Germtest paper for incubation after spray with 55 different commercial fungicides (Table 1), at doses of 500 mg. $\mathrm{Kg}^{-1}(\mathrm{ppm})$. These products consisted in registered or in process of crop registration (RET 3 Temporary registration Level 3 - MAPA). The fungicides evaluated can be an important strategy in the management of this new disease. The fungicide spray was carried out by a hand manual sprayer used in gardening. The material was sprayed at run off point (detached leaves and cotton bolls) and them immediately a conidial suspension containing Colletotrichum truncatum conidia at a concentration of $10^{4}$ conidia per $\mathrm{mL}$ was inoculated. Incubation took place at $23^{\circ} \mathrm{C}$ for 10 days. Two repetitions were performed over time (separated by 10 days) the overall experiment was reproduced another time. After incubation, the percentage of severity (\%) of diseased boll and leaf area was determined. The experimental design was completely randomized (CRD).

\section{Seedling inoculation}

Cotton seedlings with younger leaves were sprayed with all the fungicides reported in Table 1 (500 mg. Kg ${ }^{-1}$ ) and then inoculated with the virulent isolate (Colletotrichum dematium) obtained in production area of Canarana - MT at a concentration of $10^{4}$ conidia per $\mathrm{mL}$. Incubation was carried in a growth chamber for 15 days. At least a 24-hour period inside a moist chamber (100\% of humidity) is needed for the germination and infection of conidial initial inoculum (B0) on leaves and plant stem. Fifteen days after inoculation, the seedlings were evaluated by percentage of severity (\%). The experiment was carried twice replication over time and overall reproduction (vessels). Plots consisted of a single cotton plant grown up in $200 \mathrm{~mL}$ plastic cups, containing organic substrate.

\section{Data analysis}

The data were analysed using the SASMAGRI software (ALTHAUS, CANTERI, GIGLIOTI 2001; CANTERI et al. 2001). The averages were grouped in the same software by the Scott and Knott test at $1 \%$ probability $(\mathrm{p}<0.01)($ CANTERI et. al. 2001).

\section{RESULTS AND DISCUSSION}

\section{Analysis of infected material from Canarana MT and Bom Jesus MT}

After sampling and processing infected leaves and cotton bolls on GC (growth chamber), the following fungi were isolated in culture media: Colletotrichum spp., Alternaria alternata and Fusarium spp. The fungi with falcate conidia with dimensions ranging from 3 to 5 microns (width) and 25-30 microns (length) were selected in visual inspection on microscope $(40 \mathrm{x})$. The forms of conidia's visualized were similar the Colletotrichum truncatum from soybeans, since this pathogen is not reported in cotton plants the name was attributed to the newly pathogen. Further studies in molecular biology must be conducted for better understanding and discard the hypothesis that the Colletotrichum truncatum how adapted to a new host. This fungus is prevalent in infected leaves, stem, and cotton bolls (figures 1, 2, 3 and 4). | 


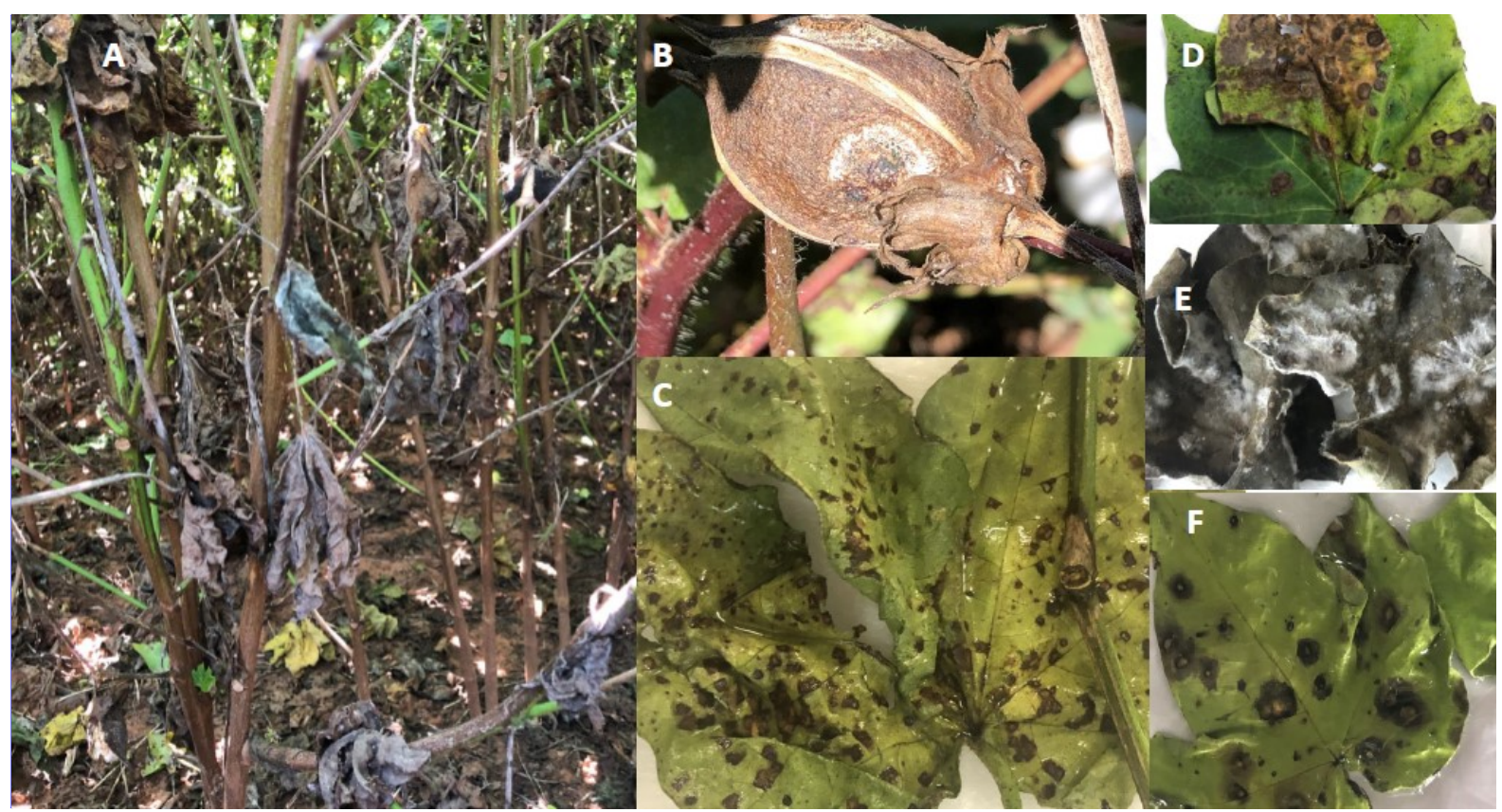

Figure 1. Symptoms of anthracnosis (Colletotrichum truncatum) in cotton plants. Leaves (A, C, D, E and F) and cotton bolls (B). Photograph. F.C.Juliatti. 2020.

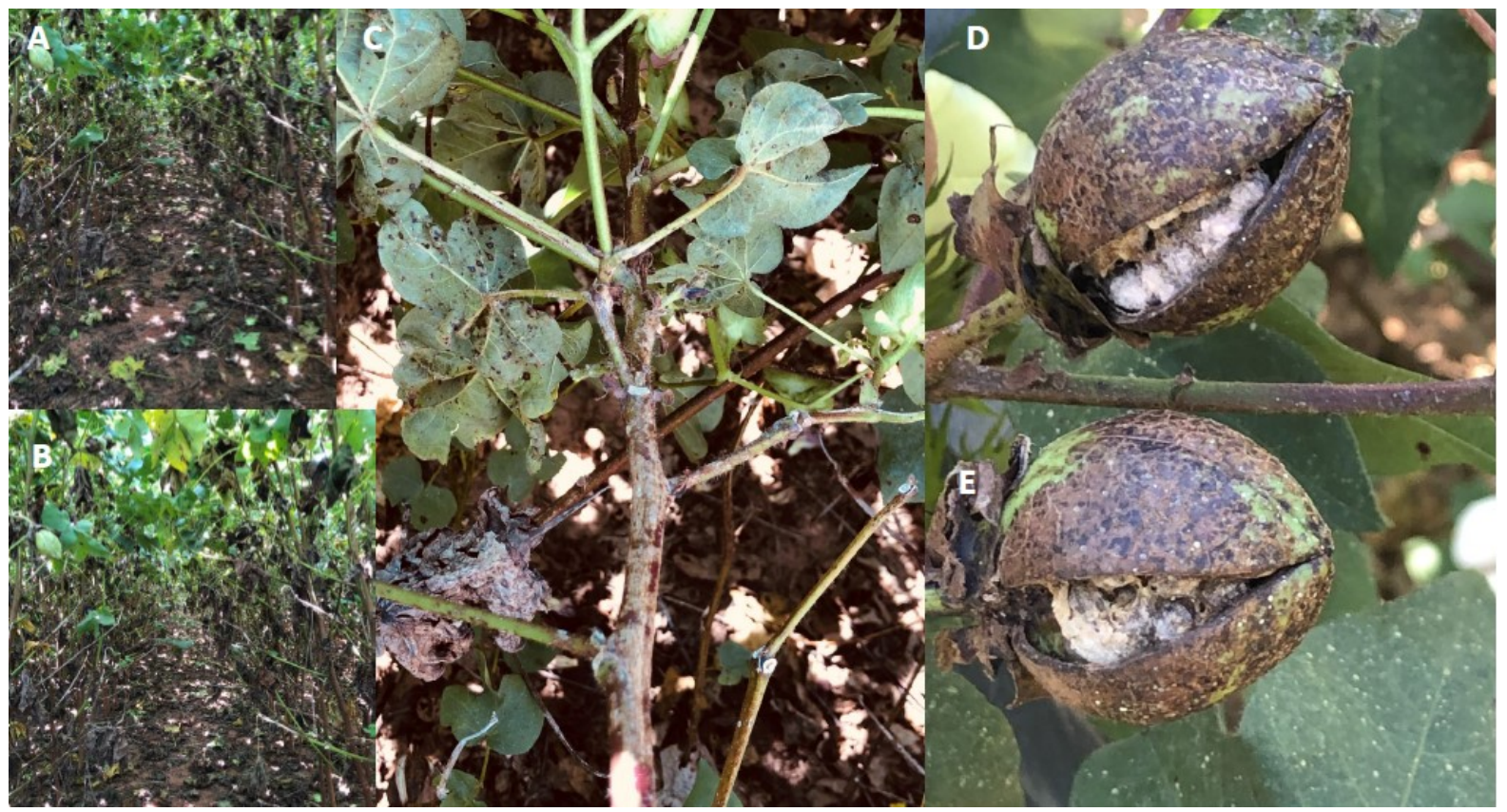

Figure 2. Aggressive loss of lower leaves at bottom plant region by the new disease infection (A and B), detail of the infection in the reddish stem on the main stem (C) and symptoms in the cotton bolls (D and E). Photograph by F.C.Juliatti 2020. 


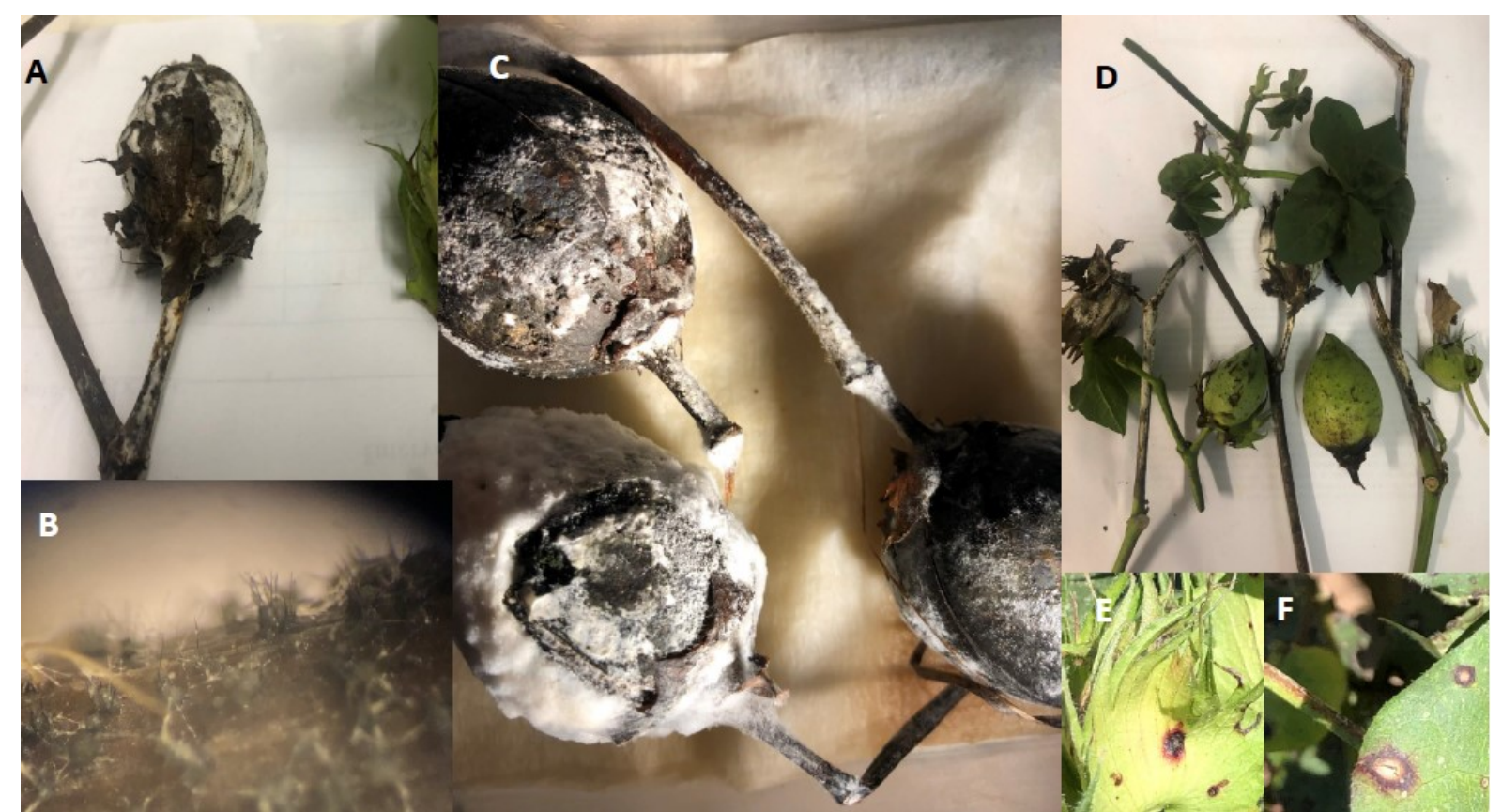

Figure 3. Details of the infection of the pathogen, with mycelial formation (A and C) and production of acervuli (B) characteristic of the species and symptoms in newly bolls formation (D, E and F). Photograph by F.C. Juliatti 2020.

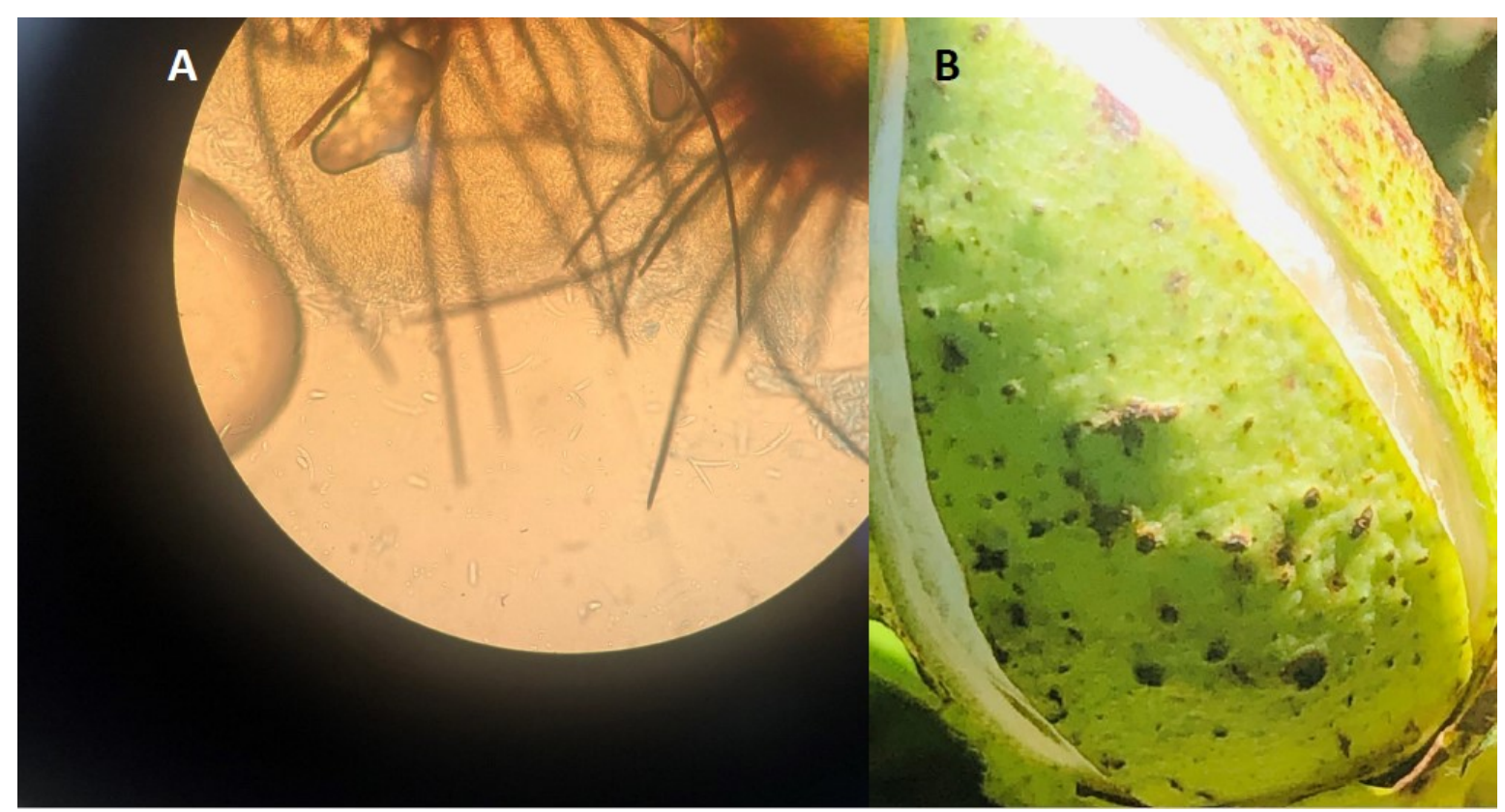

Figure 4. Production of acervuli by $C$. truncatum with spikes and formation of sickle-cell (falcate - dimensions 3-5 microns-25-30 microns) (A) and infection on cotton boll generating deformation (B). Photograph by F.C. Juliatti 2020.

\section{Pathogenicity Test}

The pathogenicity test after inoculation of the fungus Colletotrichum truncatum was confirmed, both in leaves and in detached cotton bolls. The phytopathogen grows and sporulates in PDA medium easily, at a temperature of $23{ }^{\circ} \mathrm{C}$ and photoperiod of 12 hours (figures 4 and 5). 


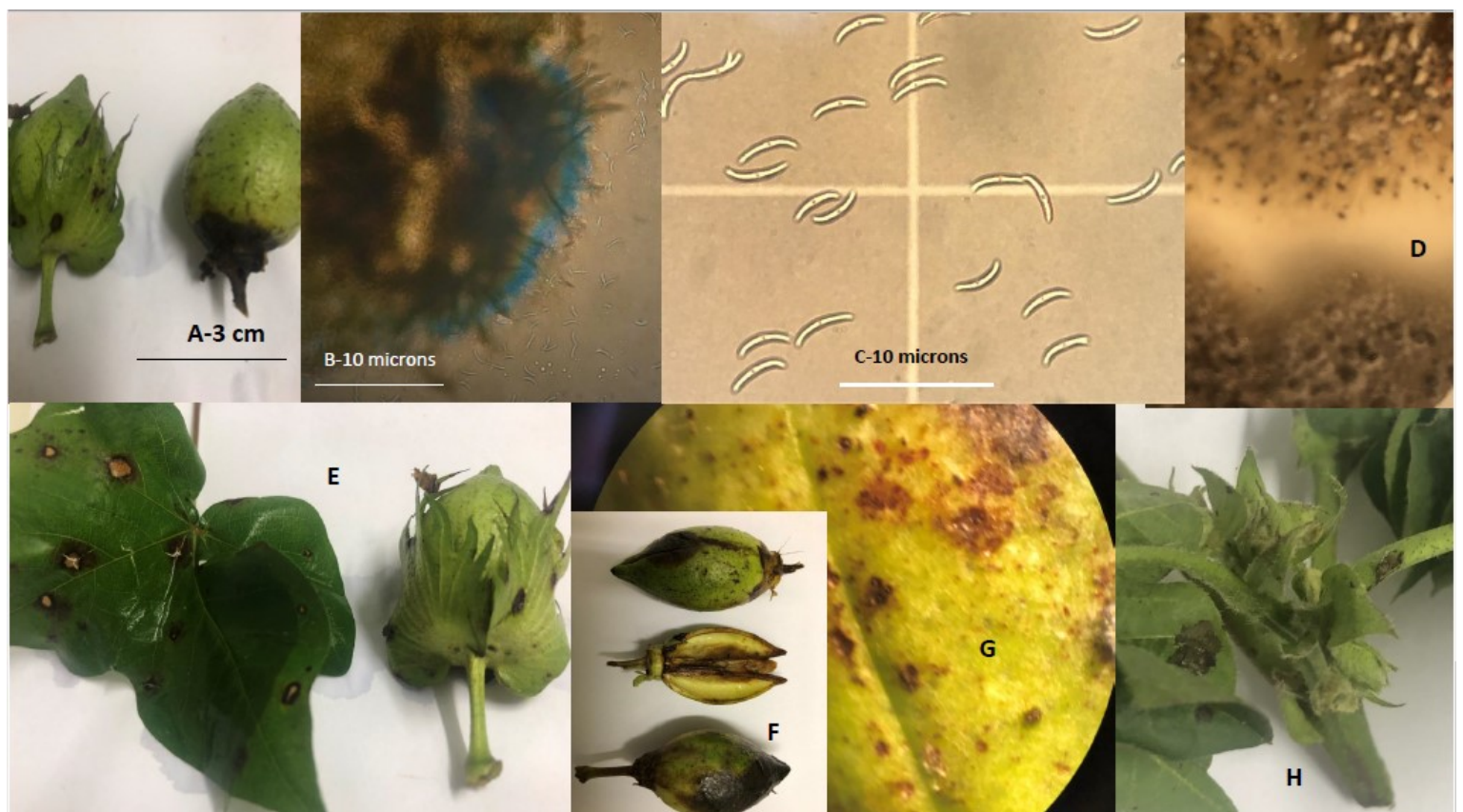

Figure 5. Floral infection (A), formation of acervuli with falcate conidia (B and $\mathrm{C}-3-5 \mu-25-30 \mu$ ), matching of compatible isolates in PDA culture medium (D) formation of ascomycete form Glomerella spp . Symptoms on leaves and cotton bolls (E, F and G) and necrosis of floral parts (H). Photo F.C.Juliatti 2020 .

Pathogenicity in young seedlings with 15 to 30 days, was observed 5 days after inoculation, with symptoms on the younger unifoliate leaf, showing symptoms typical of anthracnosis demonstrated and observed in field (Figure $6-\mathrm{A}, \mathrm{B}, \mathrm{C}$ and D). Initial circular necroses were observed five days after inoculation. They evolved from hydrosis lesions to circular and irregular necrosis. Symptoms were also observed in the reddish stems like the anthracnosis of beans and soybeans. Epidemic studies are being carried out to clarify on hosts if occurs transmission by seeds and the increasing sensitivity by genotypes / cultivars in younger plant phase (15-30 days) impacts on severity development.

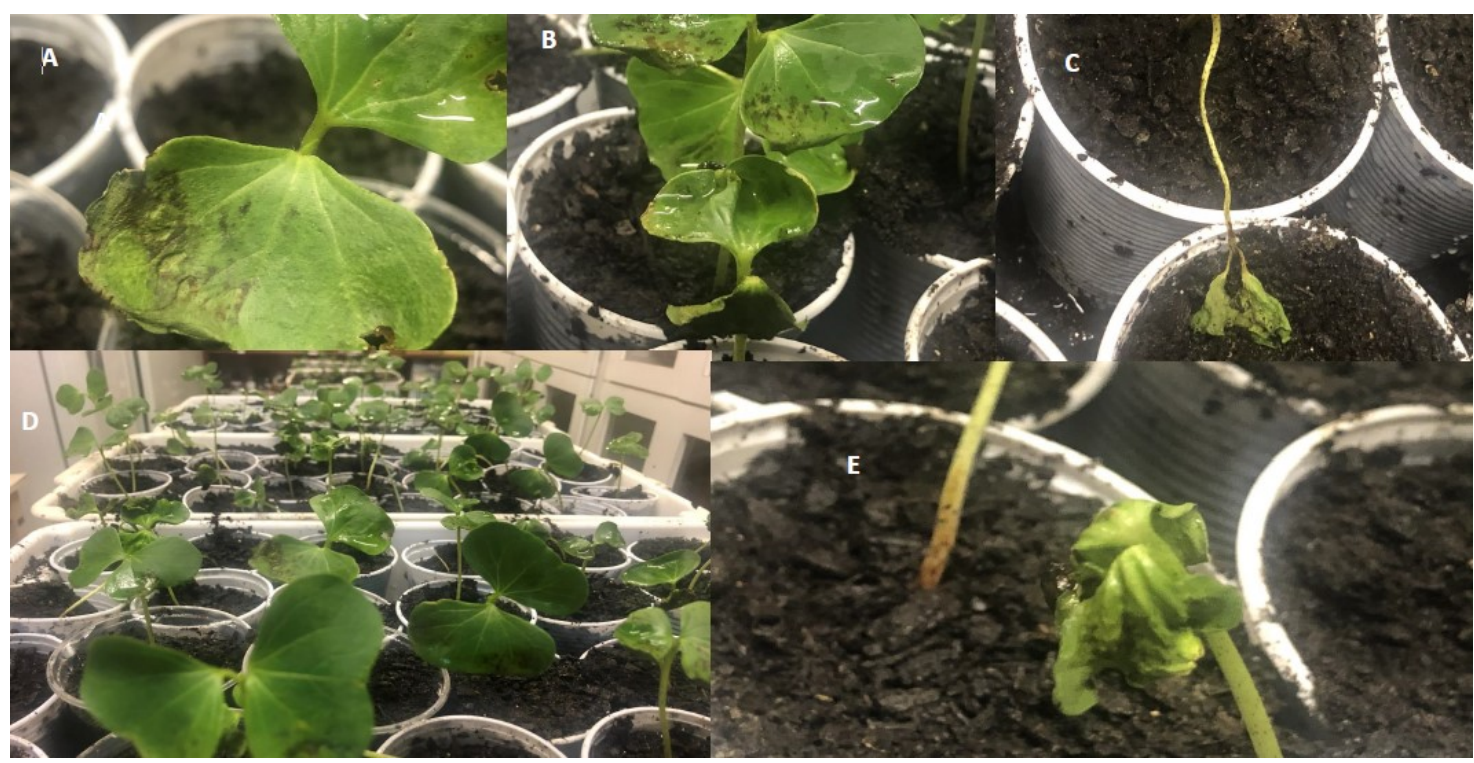

Figure 6. Typical symptoms of anthracnose in seedlings inoculated at 30 days of age and incubation at $20-30{ }^{\circ} \mathrm{C}$, prompted by Colletotrichum truncatum. Photograph by F.C. Juliatti.

Evaluation of fungicide efficiency in detached leaves and bolls
Fungicides (active ingredients - a.i.), trade names, chemical groups used in the essay are presented in Table 1, some are being used to supress 
disease development, but without field data to better clarify and solve the hypothesis of a defined strategy for this phytopathogen evolution on cotton
JULIATTI, F. C. et al

cultivation in Vale do Araguaia - MT. All fungicides were adoppted at a concentration of 500 ppm (mg. $\left.\mathrm{Kg}^{-1}\right)$.

Table 1. Fungicides used in the leaf and cotton bolls (boll) method applied in the control of cotton anthracnose caused by Colletotrichum truncatum. Uberlândia - MG, 2020.UFU, Uberlândia, 2020.

\begin{tabular}{|c|c|c|c|c|c|c|c|c|c|c|}
\hline $\begin{array}{c}\text { Commercial } \\
\text { Name or RET }\end{array}$ & Active Ingredien & & $\begin{array}{c}\text { Concen } \\
\text { ration } \\
\text { g.L } .^{-1}\end{array}$ & & Chemical Grou & & $\begin{array}{c}\text { Severity } \\
\text { Medium- } \\
\text { Leaves }(\%)^{3}\end{array}$ & $\begin{array}{l}\% \\
\text { Con } \\
\text { trol }\end{array}$ & $\begin{array}{c}\text { Severity } \\
\text { Medium - } \\
\text { Bolls (\%) }\end{array}$ & $\begin{array}{l}\% \\
\text { Con } \\
\text { trol }\end{array}$ \\
\hline 1-A20944 WG & $\begin{array}{l}\text { protioconazole } \\
\text { pydiflumetofen }\end{array}$ & + & $5.6+6.7$ & & $\begin{array}{l}\text { Triazolinthione } \\
\text { Carboxamide }\end{array}$ & + & $20 \mathrm{k}$ & 80 & $10 \mathrm{j}$ & 90 \\
\hline $\begin{array}{l}\text { 2- ABACUS®HC } \\
\text { SC }\end{array}$ & $\begin{array}{l}\text { piraclostrobina } \\
\text { ppoxiconazole }\end{array}$ & + & $\begin{array}{l}260 \\
160\end{array}$ & + & $\begin{array}{l}\text { Strobilurin } \\
\text { Triazole }\end{array}$ & + & $55 \mathrm{e}$ & 45 & $49 \mathrm{f}$ & 51 \\
\hline $\begin{array}{l}\text { 3- } \mathrm{ADA} \text { FF } \\
\text { (Armero) WG }\end{array}$ & $\begin{array}{l}\text { protioconazole } \\
\text { pancozeb }\end{array}$ & + & $40+500$ & & $\begin{array}{l}\text { Triazolinthione } \\
\text { Ditiocarbamate }\end{array}$ & + & $0 \mathrm{n}$ & 100 & $0 \mathrm{k}$ & 100 \\
\hline 4- Alto $100 \mathrm{CE}$ & piproconazol & & 100 & & Triazole & & $0 \mathrm{n}$ & 100 & $0 \mathrm{k}$ & 100 \\
\hline $\begin{array}{l}\text { 5- APPROVE } \\
\text { WG }\end{array}$ & $\begin{array}{l}\text { fluazinam } \\
\text { tiophanate metilic }\end{array}$ & + & $\begin{array}{l}375 \\
375\end{array}$ & + & $\begin{array}{l}\text { Fenilpiridinilamin } \\
+ \text { Benzimidazole }\end{array}$ & & $20 \mathrm{k}$ & 80 & $0 \mathrm{k}$ & 100 \\
\hline $\begin{array}{l}\text { 6- } \text { APROACH } \\
\text { PRIMA SC }\end{array}$ & $\begin{array}{l}\text { picoxistrobin } \\
\text { ciproconazole }\end{array}$ & + & $200+80$ & & $\begin{array}{l}\text { Strobilurin } \\
\text { Triazole }\end{array}$ & + & $22 \mathrm{k}$ & 78 & $20 \mathrm{i}$ & 80 \\
\hline $\begin{array}{l}\text { 7- } \\
\text { CE }\end{array}$ & $\begin{array}{l}\text { epoxiconazole } \\
\text { fluxapiroxade } \\
\text { piraclostrobin }\end{array}$ & $\begin{array}{l}+ \\
+\end{array}$ & $\begin{array}{l}50+5 \\
+81\end{array}$ & 50 & $\begin{array}{l}\text { Triazole } \\
\text { Carboxamide } \\
\text { Strobilurin }\end{array}$ & $\begin{array}{l}+ \\
+\end{array}$ & 81 & 92 & $30 \mathrm{~h}$ & 70 \\
\hline $\begin{array}{l}\text { 8- AUTHORITY } \\
\text { SC }\end{array}$ & $\begin{array}{l}\text { azoxistrobin } \\
\text { flutriafol }\end{array}$ & + & $\begin{array}{l}125 \\
125\end{array}$ & + & $\begin{array}{l}\text { Strobilurin } \\
\text { Triazole }\end{array}$ & + & $43 \mathrm{~g}$ & 57 & $10 \mathrm{j}$ & 90 \\
\hline 9- BIOFAC SC & $\begin{array}{l}\text { fermenteded } \\
\text { Penicillium spp }\end{array}$ & of & 1000 & & Biofungicide & & $5 \mathrm{~m}$ & 95 & $98 \mathrm{~b}$ & 2 \\
\hline $\begin{array}{l}\text { 10- } \\
\text { BRAVONIL } \circledast \\
720 \text { SC }\end{array}$ & Clorotalonil & & 720 & & Isoftalonitrile & & $5 \mathrm{~m}$ & 95 & $40 \mathrm{~g}$ & 60 \\
\hline $\begin{array}{l}\text { 11- CABRIO } \\
\text { TOP® WG }\end{array}$ & $\begin{array}{l}\text { metyram } \\
\text { piraclostrobin }\end{array}$ & + & $550+50$ & & $\begin{array}{l}\text { Ditiocarbamate } \\
\text { Strobilurin }\end{array}$ & + & $0 \mathrm{n}$ & 100 & $30 \mathrm{~h}$ & 70 \\
\hline $\begin{array}{l}\text { 12- } \\
\text { CARBOMAXx } \\
\text { SC }\end{array}$ & carbendazim & & 500 & & Benzimidazole & & $100 \mathrm{a}$ & 0 & $100 \mathrm{a}$ & 0 \\
\hline $\begin{array}{l}\text { 13- CERCOBIN } \\
700 \mathrm{WP}\end{array}$ & tiophanate metlic & & 700 & & Benzimidazol & & $30 \mathrm{i}$ & 70 & $30 \mathrm{~h}$ & 70 \\
\hline $\begin{array}{l}\text { 14- CYPRESS } \\
\text { SC }\end{array}$ & $\begin{array}{l}\text { difeconazole } \\
\text { ciproconazole }\end{array}$ & + & $\begin{array}{l}250 \\
150\end{array}$ & + & Triazole & & $0 \mathrm{n}$ & 100 & $0 \mathrm{k}$ & 100 \\
\hline $\begin{array}{l}\text { 15- COMET }{ }^{\circledR} \\
\mathrm{CE}\end{array}$ & piraclostrobina & & 250 & & Strobilurin & & $25 \mathrm{j}$ & 75 & $0 \mathrm{k}$ & 100 \\
\hline $\begin{array}{l}\text { 16- CUPRITAL } \\
700 \mathrm{WP}\end{array}$ & cupper oxychlorid & & 1196.8 & & Cupper & & $80 \mathrm{~b}$ & 20 & $30 \mathrm{~h}$ & 70 \\
\hline 17- DIFERE SC & cupper oxychlorid & & 588 & & Cupper & & $53 \mathrm{f}$ & 47 & $30 \mathrm{~h}$ & 70 \\
\hline $\begin{array}{l}\text { 18- DOMARK } \\
\text { EXCELL } \mathbb{S} S\end{array}$ & $\begin{array}{l}\text { tetraconazole } \\
\text { azoxistrobin }\end{array}$ & + & $80+100$ & & $\begin{array}{l}\text { Triazole } \\
\text { Strobilurin }\end{array}$ & + & $30 \mathrm{i}$ & 70 & $10 \mathrm{j}$ & 90 \\
\hline $\begin{array}{l}\text { 19- ELATUS }{ }^{19} \\
\text { WG }\end{array}$ & $\begin{array}{l}\text { azoxistrobin } \\
\text { benzovindiflupyr }\end{array}$ & + & $\begin{array}{l}300 \\
150\end{array}$ & + & $\begin{array}{l}\text { Strobilurin } \\
\text { Carboxamide }\end{array}$ & + & $50 \mathrm{f}$ & 50 & $30 \mathrm{~h}$ & 70 \\
\hline 20- ELEVE WP & mancozeb & & 800 & & Ditiocarbamate & & $0 \mathrm{n}$ & 100 & $0 \mathrm{k}$ & 100 \\
\hline $\begin{array}{l}\text { 21- FEZAN }{ }_{\text {GOLD }} \\
\end{array}$ & $\begin{array}{l}\text { chlorothalonil } \\
\text { tebuconazole }\end{array}$ & + & $450+50$ & & $\begin{array}{l}\text { Isoftalonitrile } \\
\text { Triazole }\end{array}$ & + & 101 & 90 & $20 \mathrm{i}$ & 80 \\
\hline $\begin{array}{l}22- \\
\text { CE }\end{array}$ & tebuconazole & & 200 & & Triazole & & $0 \mathrm{n}$ & 100 & $0 \mathrm{k}$ & 100 \\
\hline 23- FOX CE & $\begin{array}{l}\text { trifloxistrobine } \\
\text { protioconazole }\end{array}$ & + & $\begin{array}{l}150 \\
175\end{array}$ & + & $\begin{array}{l}\text { Strobilurin } \\
\text { Triazolinthione }\end{array}$ & + & $50 \mathrm{f}$ & 50 & $20 \mathrm{i}$ & 80 \\
\hline $\begin{array}{l}\text { 24- FOX XPRO } \\
\text { SC }\end{array}$ & $\begin{array}{l}\text { bixafen } \\
\text { protioconazole } \\
\text { trifloxistrobine }\end{array}$ & $\begin{array}{l}+ \\
+\end{array}$ & & & $\begin{array}{l}\text { Carboxamide } \\
\text { Triazolinthione } \\
\text { Strobilurin }\end{array}$ & $\begin{array}{l}+ \\
+\end{array}$ & $58 \mathrm{~d}$ & 42 & $60 \mathrm{~d}$ & 40 \\
\hline 25- FUSÃO $® C E$ & $\begin{array}{l}\text { metominostrobin } \\
\text { tebuconazole }\end{array}$ & + & $\begin{array}{l}110 \\
165\end{array}$ & + & $\begin{array}{l}\text { Strobilurin } \\
\text { Triazole }\end{array}$ & + & $40 \mathrm{~h}$ & 60 & $100 \mathrm{a}$ & 0 \\
\hline $\begin{array}{l}\text { 26- FUNGURAN } \\
\text { WP }\end{array}$ & cupper oxychlorid & & 840 & & Cupper & & 98 a & 2 & $100 \mathrm{a}$ & 0 \\
\hline
\end{tabular}




\begin{tabular}{|c|c|c|c|c|c|c|c|c|c|}
\hline 27- HBD $276 \mathrm{SC}$ & $\begin{array}{l}\text { chlorothalonil } \\
\text { tebuconazole }\end{array}$ & + & $750+60$ & $\begin{array}{l}\text { Isoftalonitrile } \\
\text { Triazole }\end{array}$ & + & $5 \mathrm{~m}$ & 95 & $70 \mathrm{c}$ & 30 \\
\hline $\begin{array}{l}\text { 28- HELMSTAR } \\
\text { PLUS }{ }^{8} \text { SC }\end{array}$ & $\begin{array}{l}\text { azoxistrobin } \\
\text { tebuconazole }\end{array}$ & + & $\begin{array}{l}120 \\
240\end{array}$ & $\begin{array}{l}\text { Strobilurin } \\
\text { Triazole }\end{array}$ & + & $40 \mathrm{~h}$ & 60 & $10 \mathrm{j}$ & 90 \\
\hline $\begin{array}{l}\text { 29- IMPACT } 125 \\
\text { SC }\end{array}$ & flutriafol & & 125 & Triazole & & $80 \mathrm{~b}$ & 20 & $50 \mathrm{e}$ & 50 \\
\hline $\begin{array}{l}30-\quad \text { LOCKER } \mathbb{} \\
\text { SC }\end{array}$ & $\begin{array}{l}\text { carbendazim } \\
\text { tebuconazole } \\
\text { cresoxym-metíl }\end{array}$ & $\begin{array}{l}+ \\
+\end{array}$ & $\begin{array}{l}200 \\
100 \\
125\end{array}$ & $\begin{array}{l}\text { Benzimidazole } \\
\text { Triazole } \\
\text { Strobilurin }\end{array}$ & $\begin{array}{l}+ \\
+\end{array}$ & $80 \mathrm{~b}$ & 20 & $100 \mathrm{a}$ & 0 \\
\hline $\begin{array}{l}\text { 31- MANFIL } 800 \\
\text { WP }\end{array}$ & mancozeb & & 800 & Ditiocarbamate & & $0 \mathrm{n}$ & 100 & $100 \mathrm{a}$ & 0 \\
\hline $\begin{array}{l}32-\quad \text { MERTIN }{ }^{2} \\
400 \mathrm{SC}\end{array}$ & fentin hidroxide & & 400 & Tinned Organic & & $0 \mathrm{n}$ & 100 & $10 \mathrm{j}$ & 90 \\
\hline 33- NATIVO SC & $\begin{array}{l}\text { trifloxistrobin } \\
\text { tebuconazole }\end{array}$ & + & $\begin{array}{l}100 \\
200\end{array}$ & $\begin{array}{l}\text { Strobilurin } \\
\text { Triazole }\end{array}$ & + & $20 \mathrm{k}$ & 80 & $0 \mathrm{k}$ & 100 \\
\hline 34- NKF 58 & $\begin{array}{l}\text { protioconazol } \\
\text { clorotalonil }\end{array}$ & + & $47+670$ & $\begin{array}{l}\text { Triazolinthione } \\
\text { Isoftalonitrila }\end{array}$ & + & $50 \mathrm{f}$ & 50 & $50 \mathrm{e}$ & 50 \\
\hline 35- NKF 60 CE & protioconazole & & 400 & Triazolintiona & & $0 \mathrm{n}$ & 100 & $10 \mathrm{j}$ & 90 \\
\hline 36- Opera ${ }^{\circledR} \mathrm{CE}$ & $\begin{array}{l}\text { piraclostrobin } \\
\text { epoxiconazole }\end{array}$ & + & $133+50$ & $\begin{array}{l}\text { Strobilurin } \\
\text { Triazole }\end{array}$ & + & $50 \mathrm{f}$ & 50 & $50 \mathrm{e}$ & 50 \\
\hline 37- Orkestra ${ }^{\circledR} \mathrm{SC}$ & $\begin{array}{l}\text { piraclostrobin } \\
\text { fluxapiroxade }\end{array}$ & + & $\begin{array}{l}333 \\
167\end{array}$ & $\begin{array}{l}\text { Strobilurin } \\
\text { Carboxamide }\end{array}$ & + & $45 \mathrm{~g}$ & 55 & $100 \mathrm{a}$ & 0 \\
\hline $\begin{array}{l}\text { 38- PREVINIL® } \\
\text { SC }\end{array}$ & chlorothalonil & & 720 & Isoftalonitrile & & $0 \mathrm{n}$ & 100 & $10 \mathrm{k}$ & 90 \\
\hline $\begin{array}{ll}\text { 39- } & \text { PRIORI } \\
\text { SC } & \end{array}$ & azoxistrobin & & 250 & Strobilurin & & $100 \mathrm{a}$ & 0 & $10 \mathrm{j}$ & 90 \\
\hline $\begin{array}{l}\text { 40- } \quad \text { PRIORI } \\
\text { TOP® SC }\end{array}$ & $\begin{array}{l}\text { azoxistrobin } \\
\text { difenoconazole }\end{array}$ & + & $\begin{array}{l}200 \\
125\end{array}$ & $\begin{array}{l}\text { Strobilurin } \\
\text { Triazole }\end{array}$ & + & $60 \mathrm{~d}$ & 40 & $10 \mathrm{j}$ & 90 \\
\hline $\begin{array}{l}\text { 41- } \quad \text { PRIORI } \\
\text { XTRA@ SC }\end{array}$ & $\begin{array}{l}\text { azoxistrobine } \\
\text { ciproconazole }\end{array}$ & + & $200+80$ & $\begin{array}{l}\text { Strobilurin } \\
\text { Triazole }\end{array}$ & + & $70 \mathrm{c}$ & 30 & $10 \mathrm{j}$ & 90 \\
\hline $\begin{array}{l}\text { 42- PRISMA } \\
\text { PLUS CE }\end{array}$ & difenoconazole & & 250 & Triazol & & $31 \mathrm{i}$ & 69 & $30 \mathrm{~h}$ & 70 \\
\hline $\begin{array}{l}\text { 43- } \\
\text { WECONIL }\end{array}$ & cupper oxychlorid & & 588 & Cupper & & $100 \mathrm{a}$ & 0 & $100 \mathrm{a}$ & 0 \\
\hline $\begin{array}{l}\text { 44- REDSHIELD } \\
750 \mathrm{WP}\end{array}$ & cuproson oxide & & 860 & Cupper & & $25 \mathrm{j}$ & 75 & $0 \mathrm{k}$ & 100 \\
\hline 45- SCORE CE & difeconazole & & 250 & Triazole & & $20 \mathrm{k}$ & 80 & $0 \mathrm{k}$ & 100 \\
\hline $\begin{array}{l}\text { 46- SERENADE } \\
\text { SC }\end{array}$ & $\begin{array}{l}\text { Bacillus subtil } \\
\text { line QST } 713\end{array}$ & & 13.68 & Biofungicide & & 101 & 90 & $10 \mathrm{j}$ & 90 \\
\hline $\begin{array}{l}\text { 47- } \quad \text { SPHERE } \\
\text { MAX SC }\end{array}$ & $\begin{array}{l}\text { trifloxistrobin } \\
\text { ciproconazole }\end{array}$ & + & $\begin{array}{l}375 \\
160\end{array}$ & $\begin{array}{l}\text { Strobilurin } \\
\text { Triazole }\end{array}$ & + & 20 & 80 & $0 \mathrm{k}$ & 100 \\
\hline 48- STATUS SC & cupper oxychlorid & & 588 & Cúprico & & $25 \mathrm{j}$ & 75 & $20 \mathrm{i}$ & 80 \\
\hline $\begin{array}{l}\text { 49- } \\
\text { SULFURMAX- } \\
\text { SC }\end{array}$ & sulphur & & 780 & $\underline{\text { Sulphur }}$ & & $0 \mathrm{n}$ & 100 & $20 \mathrm{i}$ & 80 \\
\hline $\begin{array}{l}50-\quad \text { SUMILEX } \\
500 \mathrm{WP}\end{array}$ & procimidone & & 500 & Dicarboximide & & $0 \mathrm{n}$ & 100 & $0 \mathrm{j}$ & 100 \\
\hline $\begin{array}{l}\text { 51-TRIZIMAN } \\
\text { WG }\end{array}$ & $\begin{array}{l}\text { azoxistrobin } \\
\text { mancozeb } \\
\text { ciproconazole }\end{array}$ & $\begin{array}{l}+ \\
+\end{array}$ & $\begin{array}{l}45+675 \\
+30\end{array}$ & $\begin{array}{l}\text { Strobilurin } \\
\text { Ditiocarbamate } \\
\text { Triazol }\end{array}$ & $\begin{array}{l}+ \\
+\end{array}$ & $0 \mathrm{n}$ & 100 & $0 \mathrm{k}$ & 100 \\
\hline $\begin{array}{l}\text { 52- UNIZEB } \\
\text { GLORY WG }\end{array}$ & $\begin{array}{l}\text { azoxistrobin } \\
\text { mancozeb }\end{array}$ & + & $50+700$ & $\begin{array}{l}\text { Strobilurin } \\
\text { Ditiocarbamate }\end{array}$ & + & $5 \mathrm{~m}$ & 95 & $10 \mathrm{j}$ & 90 \\
\hline $\begin{array}{l}\text { 53- UNIZEB } \\
\text { GOLD WG }\end{array}$ & mancozeb & & 750 & Ditiocarbamate & & $5 \mathrm{~m}$ & 95 & $0 \mathrm{k}$ & 100 \\
\hline $\begin{array}{l}\text { 54- } \\
\text { VERSATILIS }{ }^{\circledR} \\
\text { SC }\end{array}$ & fenpropimorph & & 750 & Morpholine & & 101 & 90 & $0 \mathrm{k}$ & 100 \\
\hline $\begin{array}{l}\text { 55- VESSARYA } \\
\text { SC }\end{array}$ & $\begin{array}{l}\text { picoxistrobina } \\
\text { benzovindiflupyr }\end{array}$ & + & $100+50$ & $\begin{array}{l}\text { Strobilurin } \\
\text { Carboxamide }\end{array}$ & + & $0 \mathrm{n}$ & 100 & $20 \mathrm{i}$ & 80 \\
\hline CV (\%) & & & & & & 4,96 & & 0,94 & \\
\hline
\end{tabular}

${ }^{1}$ Experimental dose used of each active ingredients was $500 \mathrm{mg} \cdot \mathrm{L}^{-1}(500 \mathrm{ppm}) ;{ }^{2}$ Averages followed by the same letter vertically (column), do not differ by the Scott and Knott at $5 \%$ Probability; ${ }^{3}$ Significant by Scott \& Knott's $1 \%$ Probability test 
If we trace a limit in consideration of evaluated fungicides (Table 1) with a standard control percentage above $80 \%, 28$ fungicides with possibilities of use in the management of the disease were categorized for foliar and 33 fungicides for cotton boll spray. We also need to establish a clear strategy for rotation of fungicides since some fungicides showed bellow of $10 \%$ control for both leaf and boll infection (reproductive and vegetative stage). The fungicides that showed $100 \%$ control in this initial screening for leaves and cotton bolls were duo and trio associations of protioconazole + mancozeb, cyproconazole, difeconazole + cyproconazole, mancozeb, procimidone, tebuconazole and azoxystrobin + mancozeb + cyproconazole. The inefficacy of carbendazim and fungicides derived from metallic copper (copper oxychloride and cuprous oxide) stands out. Proticonazole + pydiflumetofen, fluazinan + methyl thiophanate, metiran + pyraclostrobin, tetraconazole + azoxystrobin, chlorotalonil + tebuconazole, fentin hydroxide, trifloxystrobin + tebuconazole, protioconazole, trifloxystrobin, chlorotoxin, chlorotoxin, chlorothalonil, ciproconazole, sulphur $\mathrm{SC}$, azoxystrobin + mancozeb, mancozebe, fenpropimorph and picoxystrobin + benzovindiflupyr showed a minimum control efficacy around $70 \%$ for leaf and boll infection. We also noted that fungicides with the lowest control efficacy were biological, cupric, benzimidazoles + triazoles + strobilurines, benzimidazoles, carboxamide + strobilurines, carboxamide + strobilurines and carboxamide + strobilurine + triazolintione which presented a control percentage below $50 \%$ (Table 2) for both vegetative and reproductive organs. This type of information is very important to establish integrated management systems, or rotation of fungicides or active ingredients when seeking the rational management of the new epidemic focusing on biological control assisting chemical.

Table 2. Level of control (\%) of cotton anthracnose caused by Colletrotrichum truncatum on leaves and fruits (cotton bolls) detached from cotton (Gossypium hirsutum L.). UFU, Uberlândia, 2020.

\begin{tabular}{|c|c|c|}
\hline Medium (Fungicides Groups) & $\begin{array}{l}\text { \% Control } \\
\text { (Leaves) }\end{array}$ & \% Control (Bolls) - Capsules \\
\hline Biofungicides & 92 & 46 \\
\hline Benzimidazoles & 35 & 35 \\
\hline Benzimidazole + Triazole + & 20 & 0 \\
\hline $\begin{array}{l}\text { Strobilurine } \\
\text { Carboxamide }+ \text { Strobilurine }\end{array}$ & 78 & 50 \\
\hline Carboxamide + Triazolinthione & 80 & 90 \\
\hline $\begin{array}{l}\text { Carboxamide + Triazole + } \\
\text { Strobilurine }\end{array}$ & 92 & 70 \\
\hline $\begin{array}{l}\text { Carboxamide }+ \text { Triazolinthione }+ \\
\text { Strobilurine }\end{array}$ & 42 & 40 \\
\hline Cupper & 36 & 53 \\
\hline Dicarboximide & 100 & 100 \\
\hline Ditiocarbamate & 98 & 67 \\
\hline Ditiocarbamate + Strobilurine & 98 & 80 \\
\hline Tinned Organic & 100 & 90 \\
\hline Strobilurine & 75 & 100 \\
\hline $\begin{array}{l}\text { Strobilurine }+ \text { Ditiocarbamate }+ \\
\text { Triazole }\end{array}$ & 100 & 100 \\
\hline Strobilurine + Triazole & 65 & 76 \\
\hline Strobilurine + Triazolinthione & 50 & 80 \\
\hline $\begin{array}{l}\text { Fenilpiridinilamine + } \\
\text { Benzimidazole }\end{array}$ & 80 & 100 \\
\hline Isoftalonitrile & 98 & 75 \\
\hline Isoftalonitrile + Triazole & 93 & 55 \\
\hline Morpholine & 90 & 100 \\
\hline Sulphur & 100 & 80 \\
\hline Triazole & 100 & 94 \\
\hline Triazolinthione & 100 & 90 \\
\hline
\end{tabular}




\section{Reaction of genotypes by prevalence index in the upper, middle and lower thirds of plants under field conditions}

The Table 3 shows the cultivars or genotypes cultivated in the Araguaia Valley or during the experiment period and their reaction to anthracnose considering the prevalence index in the plant in the lower, middle and upper canopy of the plant, as well as the severity of symptoms and the consequent leaf destruction by Colletotrichum truncatum. The cultivar with the highest levels of severity was FM 985 GLTP, with an average severity in the evaluation on field up to $70 \%$, followed by FM 975 WS with $30 \%$ severity (prevalence index). The superior severity in the cultivar FM 985 GLTP could be hypothesized of its representative growth area, since it's one of the most cultivated cultivar/genotypes in Araguaia Valley - MT and given its productivity and fiber characteristics (source of cellulose, sugar and proteins). In some locations, the cultivar even showed a reduction of more than $60 \%$ in productivity. Given the higher virulence of this disease, its estimated the yield losses in cotton areas during the last two seasons could have reached more than 3.000 kilograms of cotton bolls per hectare.

Table 3. Reaction of cotton genotypes and cultivars under field conditions to anthracnose after 8 applications of different fungicides. Bom Jesus - MT and Canarana - MT, 2020.

\begin{tabular}{|c|c|c|c|}
\hline $\begin{array}{ll}\text { Cultivars } & \text { or } \\
\text { Genotypes } & \end{array}$ & $\begin{array}{l}\text { Reaction to anthracnosis -Colletotrichum dextructor new sp. } \\
\text { and severity }(\%)\end{array}$ & Cycle & Days \\
\hline${\text { FM } 906 \text { GLT }^{4}}^{4}$ & $S^{1}-10 \%$ & Precocious & $140-160$ \\
\hline FM 911 GLTP $^{4}$ & S - $10 \%$ & Precocious & $140-150$ \\
\hline FM $940 \mathrm{GLT}^{3,4}$ & S - $20 \%$ & Medium & $160-180$ \\
\hline FM $954 \mathrm{GLT}^{4}$ & S - $20 \%$ & Medium-Late & $160-190$ \\
\hline FM $974 \mathrm{GLT}^{4}$ & S - $20 \%$ & Late & $170-190$ \\
\hline FM 985 GLTP $^{4}$ & S - $70 \%$ & Late & $180-190$ \\
\hline FM $975 \mathrm{WS}^{4}$ & S - $30 \%$ & Medium -Late & $160-190$ \\
\hline FM $944 \mathrm{GL}^{4}$ & S - $25 \%$ & Medium & $160-180$ \\
\hline IMA $2106 \mathrm{GL}^{2,3,4}$ & $S-10 \%$ & Medium & $160-180$ \\
\hline IMA $5801 \mathrm{~B} 2 \mathrm{RF}^{2,3,4}$ & S - $20 \%$ & $\begin{array}{l}\text { Medium- } \\
\text { Precocious }\end{array}$ & $140-150$ \\
\hline IMA $7501 \mathrm{WS}^{2,3,4}$ & S - $20 \%$ & $\begin{array}{l}\text { Medium- } \\
\text { Precocious }\end{array}$ & $140-150$ \\
\hline IMA 8405 GLT $^{2,3,4}$ & $S-10 \%$ & Late & $160-180$ \\
\hline TMG $42 \mathrm{WS}^{3}$ & $S-10 \%$ & $\begin{array}{l}\text { Medium- } \\
\text { Precocious }\end{array}$ & $140-150$ \\
\hline TMG $44 \mathrm{~B} 2 \mathrm{RF}^{3}$ & S - $10 \%$ & $\begin{array}{l}\text { Medium- } \\
\text { Precocious }\end{array}$ & $140-150$ \\
\hline TMG $47 \mathrm{~B} 2 \mathrm{RF}^{3}$ & $S-10 \%$ & Medium-Late & $160-180$ \\
\hline TMG 50 WS3 & S - $10 \%$ & Medium-Late & $140-150$ \\
\hline TMG $61 \mathrm{RF}$ & S - $10 \%$ & Medium & $140-160$ \\
\hline TMG 62 RF & S - $10 \%$ & Medium & $140-160$ \\
\hline TMG $81 \mathrm{WS}^{2}$ & $S-10 \%$ & Late & $160-180$ \\
\hline TMG $91 \mathrm{WS} 3$ & S - $10 \%$ & Late & $160-180$ \\
\hline
\end{tabular}

Acronyms: (B) - Bougard, (G) Glitol Technology, (L Liberty Link, (T) Twin Link Plus and (WS) Wild Strike

1 Prevalence index in the lower, middle and upper third of infection (S- Susceptible). Plots or plots under application of fungicides with active rotation ( 8 sprays).

2 Tolerant to gall nematodes and Rotylenchus reniphormis.

3 Tolerant to glyphosate herbicide, ramularia leaf spot and ramulosis.

4 Resistant to bacteriosis, blue disease and susceptible to atypical virus disease. 


\section{CONCLUSIONS}

A level of control by different fungicides ranging from 0 to $100 \%$ was confirmed for leaves and bolls.

The prevalence index (\%) was also evaluated, considering the three regions of the plant (lower, middle and upper canopy), on different genotypes under field conditions in the final stage of plant production (130-150 days).

The genotypes that were considered in this initial screening as susceptible was FM 985 GLTP and others were gauged as with presence of some certain degree of partial resistance.

No genotype was immune to the pathogen.

It is suggested that programs and management with fungicides be revised in order to find the best active ingredients for this new pathogen, Also new studies with fungicides (biological chemical) being associated with genotypes with greater varietal resistance should be conducted for this necrotrophic and destructive pathogen surviving phase (considering lowering the initial inoculum B0).

Benzimidazole fungicides, cupric (except cuprous oxide), Benzimidazole + Triazole + Strobilurine and Carboxamide + Triazolinthion + Strobilurin should be wisely administrated in production fields focusing the disease management due to its low efficiency (below 50\%), after laboratory initial screening survey (leaves and cotton bolls).

RESUMO: O algodoeiro Gossypium hirsutum L. está em plena expansão no Brasil em área da Bahia e Mato Grosso. Em função dessa expansão novos patossistemas podem ocorrer nas áreas tropicais na região do Vale do Araguaia - MT. Foram realizados levantamentos em áreas de produção nos municípios de Bom Jesus MT e Canarana - MT nas áreas de expansão da cultura que atingem mais de 50.000 ha. Nessa região o cultivo é realizado após o cultivo da soja em uma sucessão. São comuns nessas áreas a mancha alvo (Corynespora cassiicola), mancha de ramularia (Ramularia areola) e a Cercosporiose (Cercospora gossypii). Devido as falhas nos programas, com diferentes fungicidas de controle foram realizadas inspeções nas áreas de produção do grupo Bom futuro em diferentes cultivares e sistemas de manejo. Em função da sintomatologia diferenciada e constando-se ser um novo problema foram realizados isolamentos em BDA (batata-dextrose-ágar) e realizados testes de patogenicidade em plântulas, folhas e maçãs destacadas na temperatura de $23^{\circ}$ Celsius e regime alternado de luz do dia por 12 horas. Após a confirmação da patogenicidade em plântulas, folhas destacadas, maçãs ou capulhos para Colletotrichum truncatum foram realizados bioensaios com todos os grupos de fungicidas registrados no Brasil. Foram usada a concentração de $500\left(\mathrm{mg} . \mathrm{kg}^{-1}\right) \mathrm{ppm}$ dos ingredientes ativos, de cada formulação ou fungicida. Após a pulverização dos fungicidas foi em seguida inoculado o patógeno na concentração de $10^{4}$ conídios por ml. Avaliou-se 10 dias após a incubação a porcentagem de infecção nas folhas destacadas, assim como o percentual de infecção em cada maça inoculada pelo patógeno. Confirmou-se um nível de controle pelos diferentes fungicidas variando de 0 a $100 \%$, tanto para folhas, como para maças destacadas. Também foi avaliado o índice de prevalência (\%), considerando os três terços da planta (terço inferior, médio e superior), em diferentes genótipos em condições de campo na fase final da produção das plantas (130-150 dias). Os genótipos foram suscetíveis (FM 985 GLTP) e muitos genótipos apresentaram resistência parcial. Nenhum genótipo foi imune ao patógeno. Sugere-se a revisão dos programas e manejo com fungicidas visando alternar os melhores ingredientes ativos para o novo patógeno, associado aos genótipos como maior resistência varietal, uma vez que o patógeno pode sobreviver de um ano para o outro em sementes e restos culturais. Fungicidas benzimidazóis, cúpricos (exceto óxido cuproso), benzimidazol + triazol + estrobilurina e carboxamida + triazolintiona + estrobilurina devem ser usados com cautela no controle da doença em função da sua baixa eficiência (abaixo de $50 \%$ ), em condições de laboratório (folhas e frutos maçãs destacadas).

PALAVRAS CHAVE: Algodão. Antracnose. Controle químico. Controle genético. Manejo. Nova doença.

\section{REFERENCES}

ALTHAUS, R. A., CANTERI, M. G., GIGLIOTI, E.A. Tecnologia da informação aplicada ao agronegócio e ciências ambientais: sistema para análise e separação de médias pelos métodos de Duncan, Tukey e Scott- 
Knott. Anais do X Encontro Anual de Iniciação Científica, Anais... Parte 1, Ponta Grossa, p. 280 281.2001.

BARNETT, H.L.; HUNTER, B. B. Illustrated genera of imperfect fungi. Fourth edition. APSPress, St. Paul, Mi, Minessota,218 p.1998.

BARNETT, H.L.; HUNTER, B.B.Illustrated genera of imperfect fungi. Third edition. Burgess Publishing Company, Minneapolis, Minessota,240 p.1972.

CANTERI, M. G., ALTHAUS, R. A., VIRGENS FilHO, J. S., GIGLIOTI, E. A., GODOY, C. V. SASM Agri : Sistema para análise e separação de médias em experimentos agrícolas pelos métodos Scoft - Knott, Tukey e Duncan. Revista Brasileira de Agrocomputação, 1:2, p.18-24. 2001.

COSTA, A.S.; FRAGA, J.R. Superbrotamento ou ramulose do algodoeiro. J. Agric., Piracicaba, 12:249259.1937.

JULIATTI, F. C.; POLIZEL, A. C. Manejo integrado de doenças na cotonicultura Brasileira. $1^{\mathrm{a}}$ ed. Uberlândia, MG, Edufu - UFU. 142p. 2003.

KIRKPATRICK, T.L.; ROTHROCK, C.S. (eds.). Compendium of cotton diseases. Secon edition. APS Press,St. Paul, Minessota, 87p.2001.

MALAGUTI, G. La escobilla del algodón em Venezuela. Agron. Trop., 5;73-86, Maracay, Venezuela.1955.

POLIZEL, A.C.; JULIATTI, F.C.; PENNA, J.C.V.; HAMAWAKI, O.T. Reação de genótipos de algodoeiro quanto a severidade de manchas foliares. Bioscience Journal, 24, n.3, p. 8-12. Uberlândia, MG, 2008.

VIEGAS, A.P. Índice de fungos da América do Sul. Campinas, 921 p.1957.

WATHINS, G.M. (ed.).Compendium of cotton diseases. First edition APS Press,St. Paul, Minessota. 87 p.1968.

ZAMBOLIM, L; PEREIRA, O.L. Isolamento de fungos. In: ZAMBOLIM, L; JESUS Jr, W.C. PEREIRA, O.L. (eds). O essencial da fitopatologia. Agentes causais. vol.2.p. 255-286. Suprema gráfica e editora Ltda. ISBN. 978-85-60027-33-0.2012. 